\title{
Arbobacteria - Pathogens Transmittable by Arthropods
}

\author{
Arbeitskreis Blut, Untergruppe «Bewertung Blutassoziierter Krankheitserreger»
}

\begin{abstract}
Anaplasma phagocytophilum, marginatum; Bartonella henselae; Borrelia burgdorferi, afzelii, garinii; Coxiella burnetii; Ehrlichia chaffeensis; Francisella tularensis; Rickettsia prowazekii, akari, rickettsii andYersinia pestis are also known as arbobacteria. Diseases caused by these bacteria are basically zoonoses, i.e. diseases transmittable from animals to humans, and have been known as such for about 100 years (table 1). A part of the individual pathogens have not been described until the past few decades. Based on molecular biology analyses, $R$. prowazekii, Ehrlichia and Anaplasma are categorised as Rickettsiales, while Bartonella is categorised as alpha-2-proteobacteria, Coxiella, Rickettsia grylli and F. tularensis as gamma proteobacteria, and Y. pestis as enterobacteria [1].

Most arbobacteria grow predominantly intracellularly. However, Borrelia bacteria grow intracellularly and extracellularly, and Yersinia mainly extracellularly. The above described arbobacteria, when transmitted by ticks, show seasonal occurrence and a partly changed antigen repertoire in vector and mammal. $R$. prowazekii is transmitted by lice world-wide throughout the year.
\end{abstract}

The major clinical symptoms such infections have in common include fever, exanthema, headache, and lymph node swelling, partly a pronounced erythema at the site of the sting, and encephalitic disorders. Neutropenia and thrombocytopenia can occur later.

Treatment: Doxycycline is the treatment of choice against most of these bacteria, followed by chloramphenicol and cephalosporins. Quinolones are ineffective against $R$. prowazekii. The treatment of choice against $Y$. pestis and $F$. tularensis is streptomycin or gentamycin, and in addition doxycycline or ciprofloxacine.

C. burnetii has been dealt with separately [2]. Therefore, this pathogen is not included in the present review, neither are rare tropical and/or pure tropical diseases. The oriental flea (Xenopsylla cheopsis) is considered as the most effective transmitter for $Y$. pestis. More than 30 other flea species are known which can transmit $Y$. pestis as intermediary hosts, including Pulex irritans (human flea), which can play a role in human-to-human transmission. The human louse can also be a vector for transmission of $Y$. pestis [3].

The following section provides for each pathogen information on the general state of knowledge, characteristics of the pathogen, infectious disease, epidemiology, methods of detection and occurrence of the pathogen in the donor population. This is followed by information concerning all pathogens on epidemiology, defence situation, treatment and prevention in recipient populations as well as a summary evaluation.

\section{Anaplasma and Ehrlichia}

\subsection{Current Knowledge about the Pathogen}

Today, after separation into Ehrlichia and Anaplasma, the pathogens are subdivided as follows:

- Anaplasma: A phagocytophilum, platys, marginale.

- Ehrlichia: E. chaffeensis, with horse as the major host and infection in humans, as well as Ehrlichia ewingii and Ehrlichia canis, with dog as the major host, which seldom infect humans.

Up to 1987, an Ehrlichia infection was considered as a pure animal disease. Ehrlichiosis in dog was first described in Algeria in 1935 with the characteristic inclusions in monocytes in the Giemsa staining. The first infections in humans were reported as Sennetsu Neorickettsiosis in Japan and Malaysia. The first description of the disease after a tick bite in the USA (Arkansas) was done in 1986 [4].

In 1994, A. phagocytophilum was described as a distinct pathogen and the disease human granulocytotropic anaplasmosis (HGA) ascribed to it [5].

\section{KARGER}

Fax +497614520714

Information@Karger.de

www.karger.com (c) 2008 S. Karger GmbH, Freiburg

Accessible online at:

www.karger.com/tmh
Prof. Dr. med. Rainer Seitz

Paul-Ehrlich-Institut

Paul-Ehrlich-Straße 51-59, 63225 Langen (Germany)

Tel. +49 6103 77-26 01, Fax -1250

seira@pei.de 
Table 1. Vectors for arbobacteria

\begin{tabular}{|c|c|c|c|c|c|}
\hline \multirow[t]{2}{*}{ Bacteria } & \multicolumn{5}{|l|}{ Transmission by } \\
\hline & Tick(s) & Mosquito & Louse & Flea & Smear infection \\
\hline $\begin{array}{l}\text { Anaplasma } \\
\text { Ehrlichia }\end{array}$ & $\begin{array}{l}\text { A. phagocytophila } \\
\text { E. chaffeensis } \\
\text { E. ewingii }\end{array}$ & & & & \\
\hline Bartonella & & $\begin{array}{l}\text { B. bacilliformis } \\
\text { (Lutzomyia } \\
\text { as vector) }\end{array}$ & B. quintana & $\begin{array}{l}\text { B. henselae } \\
\text { (cat flea) }\end{array}$ & $\begin{array}{l}\text { B. henselae } \\
\text { B. quintana } \\
\text { B. bacilliformis }\end{array}$ \\
\hline Borrelia & $\begin{array}{l}\text { B. burgdorferi } \\
\text { B. afzelii } \\
\text { B. garinii }\end{array}$ & & B. recurrentis & & \\
\hline Coxiella & C. burnetii & & & & C. burnetii \\
\hline Francisella & F.tularensis & F. tularensis & & & F.tularensis \\
\hline Rickettsia & $\begin{array}{l}\text { R. rickettsii } \\
\text { R. conorii } \\
\text { R. slovaca } \\
\text { R. helvetica }\end{array}$ & & R. prowazekii & R. typhi & \\
\hline Yersinia & & & $\begin{array}{l}Y . p e s t i s \\
\text { (experimentally) }\end{array}$ & $\begin{array}{l}\text { Y. pestis } \\
\text { (Xenopsylla } \\
\text { cheopsis, rat flea) }\end{array}$ & $\begin{array}{l}\text { Y. pestis from open } \\
\text { buboes and in case } \\
\text { of plague pneumonia } \\
\text { (also droplet infection) }\end{array}$ \\
\hline
\end{tabular}

\subsubsection{Characteristics of the Pathogen}

\subsubsection{Structure}

Both pathogens are small Gram-negative bacteria, growing intracellularly and forming inclusion bodies. The pathogen infects both human and animal cells and forms so-called morula cells if excessive growth occurs. Two forms of bacteria can be distinguished - a larger reticular form and a small form with a thick and dense cell wall. The cell wall does not contain any lipopolysaccharides. The surface porin proteins which are present in the wall can be coded by many genes and form the basis for antigen variability of the pathogens. Adhesins for mammalian cells are present, which contain hypervariable regions and carry a very variable portion of sugars so that re-infection with the same, immunologically different bacterium is possible.

\subsubsection{Replication}

Anaplasma and Ehrlichia replicate in cells of nymphs and adult ticks, mammals such as deer, cattle and horse as well as humans. In the blood, Anaplasma is mainly found in neutrophil granulocytes, macrophages and monocytes, seldom in lymphocytes, whereas Ehrlichia predominantly grows in monocytes and macrophages.

Ehrlichia shows a direct cytopathogenic effect in cell culture, to which part of the clinical manifestation can be ascribed. Anaplasma cannot be degraded within the neutrophil granulocytes. Apoptosis of these cells is delayed so that bacteria can be replicated over a period of several weeks.

\subsubsection{Infection and Infectious Disease}

After penetrating the skin, the pathogens grow and spread in white blood cells, and the infection manifests itself in organs such as the liver, spleen, lymph nodes, as well as kidney, lung and brain. Granuloma formation is typical of the disease.

Immune response is inhibited due to intracellular growth, the induced reduction of the number of $\mathrm{CD} 4+, \mathrm{CD} 8+$ and $\mathrm{CD} 5+$ cells, and the reduced function of the T lymphocytes. After approximately 30 days, the immune response against the pathogen can be determined via the formation of specific antibodies.

The mean incubation period is $1-4$ weeks. The major symptoms of the infection are fever, headache, myalgia and malaise. If the lungs are involved, infiltrates can be detected in the Xray examination. The average duration of the disease is 9 days, with a range of 1-60 days. Clinical outcome varies from mild symptoms to death. The outcome tends to be more severe at an advanced age of the patients.

\subsubsection{Epidemiology}

Ehrlichia is transmitted by tick. Transmission reaches its peak from May to August. Ehrlichia can be transmitted by the tick species of Amblyomma americanum, Dermatocentor, and Ixodes. Ehrlichia infections have mainly been found in North America and South-East Asia. Anaplasma is geographically distributed world-wide in regions infested with ticks. Approximately $2 \%$ of the ticks in Germany carry A. phagocytophilum [6]. Depending on the region, Ixodes ricinus ticks carry between 1 and 16\% Ehrlichia and Anaplasma, the highest rates being present in ticks that live in dunes [7]. 
Fig. 1. Ehrlichia: Typical dots in mononuclear cells of peripheral blood caused by intracytoplasmic growth of Ehrlichia as indicated by the arrows. Shown is a detail of the figure which had been published previously in Clin Microbiol Rev 2003;16:39 [92].

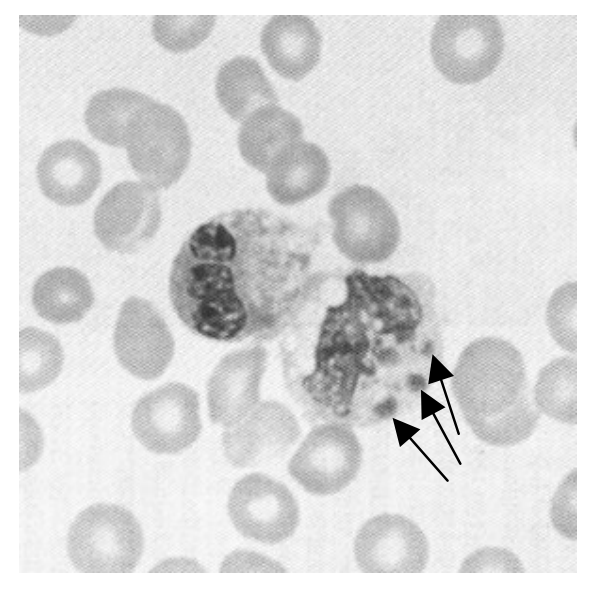

\subsubsection{Detection Methods}

\subsubsection{Microscopy and Blood Smear}

After Giemsa staining, morulae in Ehrlichia can be detected as multiple, round to oval inclusion bodies, measuring 1-3 $\mu \mathrm{m}$, in the cytoplasm of monocytoid cells of blood and bone marrow (fig. 1). The method is very insensitive, with a sensitivity of approximately $30 \%$ [8].

\subsubsection{NAT}

Polymerase chain reaction (PCR) is well suitable for clinical diagnostics. The starting material used most frequently is $16 \mathrm{~s}$ rRNA, and the primers HE1 and HE3 are used for amplification [9]. Since only few nucleotide exchanges within 1,500 bp of 16s rRNA occur between Ehrlichia and Anaplasma, distinction between these two pathogens is barely possible using this type of PCR. Specific primers have been developed for the distinction between these species [10].

\subsubsection{Antibody Detection}

Immunofluorescence test slides are commercially available. Immunoblots have been developed to increase specificity [11]. ELISA and immunoblot have been described for Anaplasma. Their diagnostic validity remains open. Serological cross-reactivity between $A$. marginale and $A$. phagocytophilum in cattle is $63 \%[12]$.

\subsection{Blood and Plasma Donors}

\subsubsection{Prevalence and Incidence in Donor Populations}

Up to now, no transfusion-associated transmission of Anaplasma or Ehrlichia has been reported in Germany. Blood donors are not tested for the presence of Anaplasma or Ehrlichia bacteria, or antibodies against the latter.

In the USA, Ehrlichia has been transmitted via liver and pancreas transplantations [13]. In blood donors with tick bites in endemic areas in the USA, the prevalence of antibodies against $A$. phagocytophilum was $0.9 \%$ [14]. An infected tick was also found in the English Garden of Munich [15, 16].

\subsubsection{Definition of Exclusion Criteria}

The general exclusion criteria apply which point to an infection, such as rise in body temperature, fatigue, exhaustion, muscle pain and anaemia. If applicable, the question should be asked whether a tick bite occurred within the last 4 weeks.

\subsubsection{Donor Testing}

\subsubsection{Antibody Determination}

Testing for antibodies is not performed. Tests are available (c.f. '1.1.4 Detection Methods').

\subsubsection{Detection of Anaplasma and Ehrlichia}

Since cultivation requires a very high workload and is expensive but does not show enough sensitivity, PCR is the method of choice, whenever required, (cf. '1.1.4 Detection Methods').

\section{Bartonella}

\subsection{Current Knowledge about the Pathogen}

The bacterium is named after A.L. Barton who described the intraerythrocytary occurrence of Bartonella quintana in 1909. Bartonella is the causative agent for the bacillary angiomatosis and the so-called cat-scratch disease. Human pathogen species include Bartonella bacilliformis, B. henselae and B. quintana. A closer genetic relationship exists with Brucella and Agrobacterium.

B. bacilliformis only occurs in the Andes of South America at altitudes of between 1,000 and 3,000 m and is transmitted by ticks and midges (species: Lutzomyia). Clinical manifestation is known as Oroya fever or Verucca peruana.

B. quintana is transmitted by lice (Pediculus humanus) and is found in persons with a low standard of hygiene. The geographical distribution of B. quintana is world-wide.

$B$. henselae also occurs world-wide. Cats seem to be an animal reservoir. In the case of a bacillary angiomatosis, cats very frequently also suffer from bacteraemia. Transmission of $B$. henselae to humans is associated with contact to cats.

\subsubsection{Characteristics of the Pathogen}

\subsubsection{Structure}

Bartonella is a small $0.6-1.0 \mu \mathrm{m}$ long Gram-negative rod which can also appear curved. The surface is covered with pili, but no flagellae are present. The bacterium uses the pili e.g. to adhere to endothelial cells. 


\subsubsection{Replication}

Bartonella replicates inside and outside human and animal cells, and in the vector. Outside the body, Bartonella shows demanding growth. Within the cell, Bartonella destroys the cytoskeleton. Infection of endothelial cells is common in all mammals.

\subsubsection{Infection and Infectious Disease}

The incubation period of B. quintana and B. henselae is 3-38 days. Acute signs of illness include chills and fever. The fever persists approximately 1-3 weeks. Febrile episodes may take up to 6 weeks. Other manifestations of the disease may include headache, pain in the retrobulbar region, swollen lymph nodes, nystagmus, myalgia, arthralgia and hepatosplenomegaly. Chronic infection with relapsing fever-like episodes may frequently occur in immunocompromised patients. Bartonella frequently causes endocarditis. The affected patients are usually afebrile.

Epitheloid angiomatosis manifests itself locally on the skin or in the lymph node. Lesions can be few millimetres or centimetres in diameter and can be similar to Kaposi sarcoma. A typical sign of Bartonella is the manifestation of swollen regional lymph nodes. Encephalopathy is very rare as well as death caused by $B$. henselae. Chronic outcome of the disease over several months has only been described in immunosuppressed patients (e.g. by HIV).

Approach to Treatment: Tetracycline, rifampicine and macrolides, preferably azithromycin, are the treatments of choice. In addition, cephalosporins and quinolones may be effective.

\subsubsection{Epidemiology}

As described above, B. bacilliformis only occurs in the South American Andes. The wild animal reservoir for B. bacilliformis has not been identified. B. henselae and B. quintana occur world-wide. Cats are major animal hosts for $B$. henselae. The disease can be prevented by avoiding contact with vectors or cats. Relapses after antibiotic treatment may occur so that a re-occurrence of Bartonella infection should not automatically be considered as a new infection.

In Italy, the prevalence of $B$. henselae antibodies in exposed patients has been indicated as 6\% [17]. In Swedish elite rangers who stood out due to their occurrence of unexpected cardiac death, the prevalence was $30 \%$ for Bartonella elizabethae, $3 \%$ for B. henselae and 1\% for B. quintana [18].

\subsubsection{Detection Methods}

\subsubsection{Antibodies}

$\mathrm{IgG}$ and $\mathrm{IgM}$ Western Blot assays have been developed, with a specificity of 70-95\% [19]. The most frequent detection test is performed using immunofluorescence with intracellularly (on Vero-cells) growing Bartonella as substrate. Sensitivity is approximately $90 \%$. ELISA is commercially available. High cross-reactivity exists between antibodies against $B$. henselae and those against B. quintana.

\subsubsection{Culturing in Medium}

If the transport period to the laboratory is short, Bartonella grow in sophisticated culture media such as fresh blood agar and chocolate agar, manifesting themselves as small yellowish, smooth pleomorphic colonies. Blood culture is positive in the case of bacteraemia. Bartonella has been isolated from tissues such as liver, spleen, lymph nodes and skin.

Microscopically, Gram-negative rods can be seen but also round shapes.

\subsubsection{NAT}

A PCR method has been described by Handley and Regnery [20] to distinguish between pathogenic Bartonella species.

\subsection{Blood and Plasma Donors}

\subsubsection{Prevalence and Incidence in Donor Populations}

Bacteriaemia can develop in chronically infected asymptomatic individuals over a long period. A report is available describing the transmission of Bartonella by blood transfusion in cats [21]. No studies are available on the prevalence in blood donors in Germany. Transmissions have not been reported.

\subsubsection{Definition of Exclusion Criteria}

Typical non-specific symptoms of an infection are general exclusion criteria. Skin efflorescence pointing to angiomatosis should be another criterion for temporary donor exclusion.

\section{Borrelia}

\subsection{Current Knowledge about the Pathogen}

Borrelia is an intracellularly and extracellularly growing Spirochaeta-like bacterium, which occurs world-wide and is essentially transmitted by ticks in North America, Europe and Asia (Ixodus and Dermatocentor species). The association of tick bite, infection with B. burgdorferi and acute Lyme disease was found in 1976 [22]. In 1941, Bannwarth [23] described inflammatory polyneuritis caused by Borrelia. Herxheimer and Hartmann [24] described acrodermatitis chronica atrophicans in 1902, and Afzelius [25] described erythema chronicum migrans in 1909.

$B$. burgdorferi sensu lato is subdivided into 3 pathogenic groups: B. burgdorferi sensu strictu, the only strain in Northern America, and in addition, the B. afzelii and B. garinii groups in Europe. Up until recently, Borrelia valaisiana was classified as non-pathogenic.

Transfus Med Hemother 2008;35:374-390 


\subsubsection{Characteristics of the Pathogen}

\subsubsection{Structure}

Borrelia carries a cytoplasmatic membrane, surrounded with periplasma containing the flagella insertion, and an outer membrane the components of which are not firmly connected with the periplasma. Borrelia has a diameter of $0.3-0.5 \mu \mathrm{m}$ and a length of 8-30 $\mu \mathrm{m}$. It carries 7-11 flagellae. The linear chromosome is approximately $950 \mathrm{~kb}$ in size. Nine circular and 12 linear plasmids contribute to the genome. Borrelia contains many lipoproteins such as Osp A to F (outer surface protein) [26]. Various proteins are expressed in different ways during an infection, e.g. VIsE (variable major protein-like sequences expressed) [27] and Salp15 [28].

\subsubsection{Replication}

Borrelia grows both intracellularly and extracellularly on mammalian cell cultures under microaerophilic and anaerobic conditions. Borrelia can also be cultured as biopsy material in Barbour-Stoenner-Kelly-II culture medium. Up to now, it has not been possible to achieve replication in solid culture media. The period of generation is $7-20 \mathrm{~h}$ at $30-33{ }^{\circ} \mathrm{C}$ [29]. Each human cell can be infected, including synovial cells.

\subsubsection{Infection and Infectious Disease}

Clinical pathogenicity partly derives from the expression of different proteins. Thus, Osp $\mathrm{C}$ is barely present in the tick but is highly expressed in the mammal. The same applies to the VIsE. Since these antigens constantly change, the immune response is compromised time and again. Infection occurs by tick bite. 3-32 days later, Borrelia replicates in local tissue, usually the skin. Borrelia spreads in the body within a few days or weeks, which can lead to bacteriaemia and also infection of the central nervous system. Further preferred replication sites include the myocardium, liver, muscle, retina and spleen.

Osp C, DbpA and DbpB (decorin binding protein), fibronectin binding protein (BBK32 - $47 \mathrm{kDa}$ protein) and VIsE are responsible for the induction of inflammation mediators, depending on the strain.

The disease is subdivided into three stages:

Stage 1 Local Infection: In $>50 \%$ of the infected individuals, erythema chronicum migrans develops, even though a tick bite is not remembered, since nymphs fall off after feeding on blood. The centre of the erythema may cause a burning or itching sensation and does not necessarily show the characteristic reddening.

Stage 2 Disseminated Infection: After a few days or weeks after the tick bite, multiple lesions develop on the skin as a sign of the haematogenous seed, together with fever, fatigue, exhaustion, and regional lymph node swelling. Meningeal irritation is possible and also hepatitis, splenomegaly, cardiomyopathy, osteomyelitis and panophthalmitis.

Stage 3 Persistent Infection: Months or years after the tick bite, intermittent swelling of the joints, arthritis, axonal neuropathy, encephalomyelitis, with ataxia and cognitive disorders occur, or years after infection, acrodermatitis atrophicans with red painful sclerosing or atrophic induration of the skin. Borrelia can be detected in the tissue affected even after long persistence.

Borrelia can be transmitted to the foetus during pregnancy [30].

\subsubsection{Epidemiology}

In the northern hemisphere, Borrelia is wide-spread in North Africa, Europe, including Scandinavia and Russia, China and Japan, and in many other countries. Depending on the endemic area and lifestyle, $1-2 \%$ of the population can be infected. Prevalence is higher among forest workers. In the Bavarian Forest e.g. it is 30\% [31], and in Italy 7\% compared with the general population in the Toscana of $3 \%$ [32]. The population in the province around Madrid in Spain also showed an antibody prevalence of $3 \%$ [33].

In Southwest and Central Asia, further Borrelia strains, e.g. Borrelia recurrentis, are transmitted and cause recurrent fever, usually by ticks such as Ornithodorus and the lice, P. humanus. In Germany, Borrelia occurs in all regions in which ticks live. Up to $30 \%$ of the ticks can be infected with the 3 species $B$. burgdorferi sensu stricto, B. garinii and B. afzelii. On average, $11 \%$ of the ticks are infected in central and southern Germany. Older ticks have a higher infection rate. The predominant of the three species is B. garinii with $60 \%$, followed by $B$. burgdorferi with $32 \%$, and B. afzelii with $18 \%$ [6]. B. valaisiana can occur in $6 \%$ of the ticks. Double and few triple infections also occur [6]. In the Netherlands, the infection rate of ticks is between 0.8 and $11.5 \%$ [7].

People in all age groups can be infected. Depending on the geographical region, seasonal tick activity in Germany lasts from May to October or from March to November.

\subsubsection{Detection Methods}

\subsubsection{Antibodies}

The screening test generally used is ELISA, which contains bacterial lysate, recombinant proteins, or a combination of the latter, depending on the manufacturer. $\operatorname{IgG}$ and $\operatorname{IgM}$ can be detected; IgM can persist over a period of months up to several years. False-positive reactions are not unusual. Therefore, ELISA reactivity is confirmed via immunoblot. Several interpretation criteria have been determined for the immunoblot [34].

\subsubsection{Indirect Immunofluorescence Assay}

The indirect immunofluorescence assay serves as specificity control. Antibodies from patients are absorbed with Treponema phagedenis, and then incubated on slides with Borrelia cultivated in medium. Antibody titres must be quantitatively evaluated. Experience is required for correct interpretation. 


\subsubsection{Immunoblot}

Currently used immunoblot strips are supplemented with recombinant VIsE [27]. The main indication for the use of immunoblots is the clarification of false-positive ELISA results and the serological clarification of neurologic borreliosis.

\subsubsection{Culturing in Medium}

Culturing may be successful in Barbour-Stoenner-Kelly-II medium [29]. This is very time-consuming and requires a high workload on the part of the staff. It is therefore not routinely used.

\subsubsection{Microscopy}

Microscopic analysis shows Borrelia as weakly stainable, Gram-negative motile rods. In the blood smear, B. recurrentis can normally only be seen during the acute infectious phase.

\subsubsection{NAT}

PCR or derived methods are the methods of choice for the detection of Borrelia. PCR can be carried out in all tissues, partly after enriching the 16s DNA.

Sensitivity is between 80 and 95\% [35], depending on the primer selection from the Osp A. There is a range of sensitivity between $50-75 \%$ dependent on the species, i.e. when $B$. burgdorferi primers are used for the amplification of $B$. garinii or B. afzelii Osp A-gene [36].

\subsubsection{Animal Experiments}

Borrelia grows in mice, particularly in the gerbil, and also in rats and hamsters.

\subsection{Blood and Plasma Donors}

\subsubsection{Prevalence and Incidence in Donor Populations}

Seroprevalence of blood donors in Germany and Switzerland does not differ from that of the local population. It was $2.7 \%$ in Hamburg and Würzburg and 33\% in Solothurn [37-39]. Nine blood recipients had no antibodies against Borrelia [38] after seroconversion of the donor during follow-up, pointing to low transmission effectiveness. No transmission of Borrelia by transfusion has so far been reported in Germany.

In case of bacteriaemia, Borrelia can certainly survive at $4{ }^{\circ} \mathrm{C}$ during the storage period of the red blood cells, as shown in studies performed by Johnson et al. [40] and by Nadelman et al. [41]. A study in an endemic region such as Connecticut on the risk of Borrelia transmission by blood transfusion showed that practically no transmission takes place [42].

\subsubsection{Definition of Exclusion Criteria}

After Borrelia infection by tick bite followed either by local or the usual general signs of inflammation, Lyme disease with its clinical manifestations of fever, fatigue, and exhaustion will be detected by the usual exclusion criteria.

Arbobacteria - Pathogens Transmittable by Arthropods
If required, the donor can be asked whether a tick bite occurred within the past 6 weeks, however, this is not a reliable exclusion criterion since, as mentioned above, nymphs fall off after the bite, leaving it unnoticed.

\subsubsection{Donor Testing and Significance}

To date, blood donors have not been tested routinely for the presence of Borrelia antibodies. The current epidemiological situation still does not justify general donor screening for Borrelia [38].

\subsubsection{Antibody Determination}

Borrelia antibody determination using ELISA is very sensitive if an incubation period of approximately 4-6 weeks has elapsed. Immunoblot is carried out to exclude false-positive reactions (cf. 3.1.4 'Detection Methods').

\subsubsection{Direct Detection for Borrelia}

If an infection is suspected, detection is best carried out with plasma after enrichment via centrifugation or by means of fine-needle biopsy from the inflamed skin around the tick's stinging site. General donor testing for Borrelia, e.g. using PCR, is not required.

\subsubsection{Donor Interviews}

Donors are partly interviewed on a possible exposure after tick bite. This is of little informational value during the winter months. Other signs of bacterial infection, e.g. fever, are recorded based on the usual exclusion criteria.

\subsubsection{Donor Information and Counselling}

Comprehensive advice is necessary only if the tick bite has been remembered as having occurred within the most recent 1-2 months. In addition to information on Borrelia, this advice should also include other relevant arbobacteria and also arboviruses such as tick-borne meningo-encephalitis virus [91].

\section{Francisella tularensis}

\subsection{Current Knowledge about the Pathogen}

The genus Francisella is part of the sub-class of gammaproteobacteria and the order of Thiotrichalis. It forms a family in its own right: the Francisellaceae which is closely related to the family of the Piscirickettsiaceae, and also represents the next relative of the order of Legionellalis (Coxiella, Rickettsiella). The bacterium was isolated by McCoy and Chapin [43] from a dead gopher in Tulare, CA, in 1910. 10 years later, Frances [44] described the disease more accurately as deer-fly fever, and also described the human infection [44]. Francisella occurs endemically in the entire northern hemisphere, especially in animals living near or on the ground such as rodents and more than 100 other mammals. The natural reservoir has 
Fig. 2. Cystein-heartblood agar plate with colonies of $F$. tularensis (PD R. Grunow, Robert Koch-Institute, Berlin, Germany).

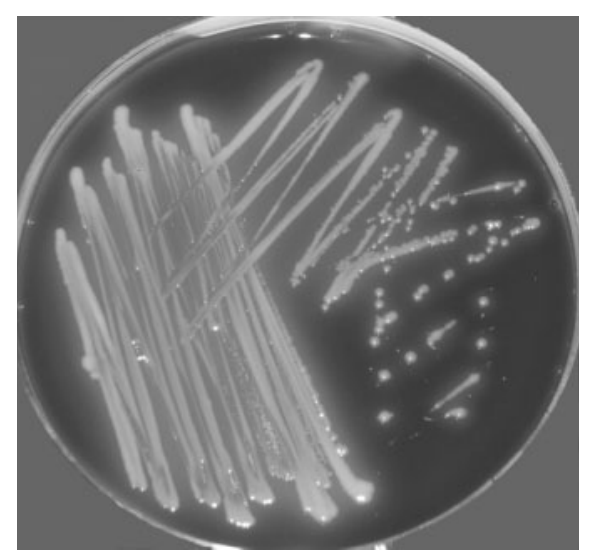

not yet been identified. It is, however, assumed that the pathogen persists in the environment under certain circumstances and in certain animal organisms over a period of months or years.

In addition to transmission by contact with infected animals, laboratory infections also occurred [45]. Francisella is transmitted through arthropods as vector, including ticks and midges, as well as by direct contact with infected animals and contaminated environmental materials [46]. Transmission from human to human is unlikely.

There are two species within the Francisella genus: Francisella philomiragia and F. tularensis. The latter is subdivided into 4 sub-species of which F. tularensis ssp. tularensis (occurrence in North America) and ssp. holarctica (occurrence in Europe and the entire northern hemisphere) are predominantly human pathogenic [47]. These pathological pictures are related to the entry site of the pathogen and are often characterised by lymph node swelling and skin ulcers. F. philomiragia was found in water and soil samples in Texas [48].

F. tularensis ssp. tularensis is considered as hazardous agent potentially usable as biological weapon, and requires culturing under level 3 biosafety laboratory conditions.

\subsubsection{Characteristics of the Pathogen}

\subsubsection{Structure}

Francisella is a relatively small, faintly stainable, Gram-negative, coccoid, aerobically growing, greyish-white, colony-forming, catalase-positive bacterium. It is immobile, does not form spores and has an electron-transparent lipid-rich capsule which contributes to the virulence of the pathogen.

\subsubsection{Replication}

Francisella grows in the laboratory in sophisticated culture media with blood and a high cystein content, preferably heartcystein-blood agar, but also chocolate agar or Thayer-Martin agar, which is suitable for gonococci. The culture grows at 37 ${ }^{\circ} \mathrm{C}$ into greyish-white shiny colonies, approximately $3-5 \mathrm{~mm}$ in size, in a humid atmosphere with $5-10 \% \mathrm{CO}_{2}$ within $2-5$ days. (fig. 2).
Fig. 3. Francisella: Intracellularly accumulated Gram-negative small red shaped bacteria shown within the ovals and restriction to the cytoplasm of one cell as indicated by the black line. Shown is the section of a figure published in ASM News 2003;11:560 [49] previously.

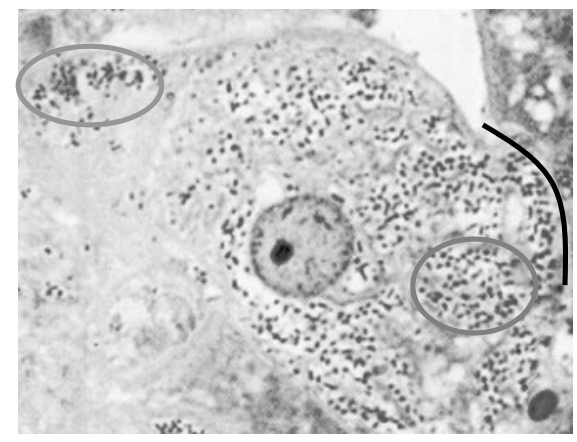

10-50 organisms form 1 HID (human infectious dose) after inoculation or inhalation. Approximately $10^{8}$ organisms are required for infection via food. After ingestion, the bacteria replicate intracellularly in lymphoid tissues. Cells of the reticulohistocytic system represent the primary target cells, but hepatocytes are also infected (fig. 3) [49]. Immune response is primarily $\mathrm{T}$ lymphocyte-mediated. Antibodies indicate that exposure has taken place. Papule, ulcer and granuloma formation, which may necrotise at a late stage, are characteristic for the disease.

In water, Francisella can replicate in amoebae [50]. Infected amoebae are not killed, however, Francisella loses some of its virulence in the mouse test by passing into the amoeba.

The bacteria retain their stability under cool and humid conditions for several weeks to months. The pathogen is sensitive to commercial disinfectants and heat treatment. Typically, the bacteria can be killed when treated at temperatures as low as $60{ }^{\circ} \mathrm{C}$ for $1 \mathrm{~h}$.

\subsubsection{Infection and Infectious Disease}

Clinical manifestation essentially depends on the number of inoculated bacteria, their virulence and the host's immune response. The spectrum of disease varies from asymptomatic infection over severe sepsis to death. The incubation period is $3-5$ days on average, and ranges from 1-21 days. The infection can be accompanied by sudden occurrence of fever, chills, headache, fatigue, cough, myalgia, breathing trouble and diarrhoea. The fever rises above $39{ }^{\circ} \mathrm{C}$ and persists for a few days. Activation of the MgIA-regulated genes during growth in the macrophages plays an important part for virulence and pathogenicity [51]. As a rule, the disease can be well treated with an appropriate antibiotic. Depending on the type of pathogen, the lethality rate is as high as $30 \%$ or higher in untreated cases [52].

The ulceroglandular form with the typical swelling of the regional lymph nodes develops after inoculation of the pathogen via arthropods or direct contact with contaminated animals, carcass, excrements or other environmental materials. All signs of inflammation accompany the main ulcer, the edge of which hardens. Necrosis in the lymph node may suppurate and 
break through towards the interior or the exterior. Super-infections with other bacteria are not unusual.

The oculoglandular form occurs relatively seldom and is usually caused by smear infection. In rare cases, contaminated dusts or aerosols may be the cause.

Oropharyngeal tularaemia manifests itself after oral ingestion of Francisella-contaminated food or water. In addition to general symptoms, an almost exclusively one-sided cervical lymph node swelling is characteristic of the disease.

Respiratory tularaemia occurs after inhalation of contaminated dusts and aerosols, usually during farming activities and presents the most severe clinical outcome of tularaemia. In addition to general symptoms, it can manifest itself as a pneumonia-like disease with cough, chest pain and increased respiratory rate. F. tularensis can replicate directly in the alveolar epithelial cells after inhalation [53]. Secondary pneumonia after haematogenic spread of the pathogen is also possible. If the pneumonia persists for longer periods, granuloma formation in the X-ray picture can resemble that of tuberculosis.

The term 'typhoid tularaemia' was applied in the past if no typical external signs of tularaemia were visible. Today, this term should only be used in certain circumstances if the route of infection cannot be detected.

Skin erythema occurs in a third of the Francisella-infected population 2-3 weeks following infection. This is a manifestation of the bacterial spread and incipient immune response. Absceding and liquefying lymph nodes occur even if the acute signs of illness have subsided.

\subsubsection{Epidemiology}

F. tularensis has its geographical distribution in the entire northern hemisphere. Persons with a particularly high risk include hunters, farmers, foresters and other groups exposed to outdoor activities for professional or leisure reasons. Among animals, rodents are the preferred reservoir for Francisella, but the pathogen also occurs in other mammals and birds. Besides direct contact, arthropods also play an essential part as vectors in the transmission to humans. A prevalence of $0.1-2 \%$ has been described for European ticks [54]. Thus, 2\% of the ticks in endemic areas are infected with Francisella in the Czech Republic and in Austria [55]. Transmission occurs by tick bite of the Ixodes, Dermatocentor, Amblyomma species as well as midges of the Aedes, Culex, and Anopheles species [46]. A third of the 27 hunters and herders in a hare hunt developed $F$. tularensis infection, partly with acute manifestations, in the 'Landkreis' (rural district) of Darmstadt-Dieburg [56] in Hesse, Germany, in 2005 [56].

The occurrence of Francisella in freshwater amoebae and the possibility of spreading in water are addressed in Section 4.1.1.2.

\subsubsection{Detection Methods}

\subsubsection{Antibodies}

Approximately 2 weeks after the occurrence of the clinical symptoms, IgG, IgA, and IgM antibodies can be detected simultaneously. The antibodies thus formed persist for more than 10 years. Available rapid tests include tube or plate agglutination tests the sensitivity of which does not exceed $100 \%$ [57]. ELISA and Western Blot assays are used as screening and confirmation tests. These tests are highly sensitive and specific for the holarctica and tularensis subspecies. However, they are currently not yet commercially available and must be adapted to European or North American Francisella strains, depending on the requirements $[58,59]$.

\subsubsection{Culturing in Medium}

F. tularensis does not grow in standard bouillon such as Luria Bertani (LB). The bacterium grows into colonies on blood culture medium enriched with cystein within approximately $48 \mathrm{~h}$ at $37{ }^{\circ} \mathrm{C}$ under aerobic conditions with $5-10 \% \mathrm{CO}_{2}$. For clinical samples, culturing is best carried out by using smears of skin ulcers or blood. Targeted culturing requires laboratories with biosafety level 3 (in Germany, however, the holarctica subspecies is classified as a pathogen of biohazard level 2). Accompanying flora suppresses the growth of Francisella. Suitable mixtures of antibiotics for the shielding of cultures, especially those from environmental samples, are currently being developed. Environmental samples should first be concentrated using 0.45 or $0.22 \mu \mathrm{m}$ filters, followed by cultivation of the filtered material.

\subsubsection{Animal Experiment}

Another way of culturing is the inoculation of the mouse with material to be tested. F. tularensis will grow in the mouse within one week.

\subsubsection{NAT}

Several commercial PCR tests for the detection of F. tularensis identify the genomic region of Francisella outer membrane protein fopA [60] or the 17-kDa lipoprotein. Differentiation of the subspecies is in most cases successfully carried out using RD1-PCR [62]. PCR is more sensitive than culturing. A TaqMan method for the detection of the bacterium in mammals and vectors has been described [63], and so have a number of other molecular methods for typing Francisella.

\subsection{Blood and Plasma Donors}

\subsubsection{Prevalence and Incidence in Donor Populations}

In Germany, no transmission of $F$. tularensis via blood has been described to date. A report on the transmission of $F$. $t u$ larensis via a kidney transplant is available from Saint Louis, MO, USA. In this report, the infection in the recipient was suc- 
cessfully treated with antibiotics following the diagnosis in the donor [64].

\subsubsection{Definition of Exclusion Criteria}

The general exclusion criteria for donors apply to donors with signs of infection. The main cause of contracting Francisella infection in Germany is an injury during gutting of infected hares or the consumption of contaminated meat from hare [56].

\subsubsection{Donor Testing and Significance}

Because of the epidemiological situation with very low infection numbers and without any known transmission of $F$. tularensis via blood in Germany, testing is currently not required.

\section{Rickettsia}

\subsection{Current Knowledge about the Pathogen}

Rickettsia is a small Gram-negative obligate intracellular parasite found in mammals, belonging to the alpha proteobacteria species. From the family of Rickettsia, the species Ehrlichia, Anaplasma, and Orienta (Orienta tsutsugamushi) have been separated based on genetic analyses. The various different Rickettsia types are partly categorised into the spotted fever group (SFG - Rickettsia africa, Rickettsia conori, Rickettsia sibirica, Rickettsia slovaca, $R$. rickettsii, Rickettsia honei and Rickettsia japonica) and the typhoid group (TG - Rickettsia typhi and $R$. prowazekii). This classification has not yet been internationally recognised (table 2).

\subsubsection{Characteristics of the Pathogen}

\subsubsection{Structure}

Rickettsia is a genus of Gram-negative bacteria that presents as rods of 0.4 to approximately $1.5 \mu \mathrm{m}$ in length. Rickettsia is faintly stainable and not easily visible if Gram staining is applied so that the preferred method is acridine orange staining. The genome is very small, with 1.1-1.6 Mbp. The cell wall contains lipopolysaccharides, peptidoglycans and the outer membrane protein $\mathrm{P}$ (Omp P), a small surface protein with approximately $135 \mathrm{kDa}$, and a $17 \mathrm{kDa}$ lipoprotein [65]. The proteins Omp A and Omp B are only intermittently expressed on the surface during maturation of the bacteria. The lipopolysaccharides of the different Rickettsia lead to immunological crossreaction. Rickettsia carry a carbohydrate layer on their surface. They are freely motile within the mammalian cell. In the vector, Rickettsia bacteria are transmitted transovarially so that, if they are present in large quantities and replicate strongly, horizontal transmission to the infected mammal is also possible [66].
Table 2. Rickettsia with significance for Europe

\begin{tabular}{|c|c|c|}
\hline Rickettsia & Vector & Disease \\
\hline R. akari & midge & rickettsial pox \\
\hline R. conorii & tick & boutonneuse fever, tick bite fever \\
\hline R. helvetica & tick & spotted fever with slowly healing papules \\
\hline R. slovaca & tick & spotted fever with slowly healing papules \\
\hline R. felis & cat flea & cat flea spotted fever (except for humans) \\
\hline R. prowazekii & louse & $\begin{array}{l}\text { epidemic spotted fever, Brill-Zinsser dis- } \\
\text { ease - which occurs years after infection, } \\
\text { cross-reaction with Proteus OX19 (Weil } \\
\text { Felix reaction). The louse dies of the R. } \\
\text { infection, louse faeces are infectious. }\end{array}$ \\
\hline R. sibirica & louse, tick & spotted fever with slowly healing papules \\
\hline R. typhi & flea & murine spotted fever; 'Fleckfieber' \\
\hline R. rickettsii & tick & $\begin{array}{l}\text { Rocky Mountains spotted Fieber (only } \\
\text { North America - patient's travel history) }\end{array}$ \\
\hline
\end{tabular}

\subsubsection{Replication}

Rickettsia replicates in cells of the vector and in great numbers of cells of the infected mammal. Rickettsia can be cultured and replicated on Vero, HEL and L929 cells.

\subsubsection{Infection and Infectious Disease}

Rickettsia bacteria are spread via the lymph and blood pathways following inoculation. They adhere to the surface of endothelial and other cells via the proteins Omp A and Omp B. They are phagocytised, escape lysis in the phagosome and move into the cell core. There, they replicate by longitudinal division, are moved to cell surface along the actin skeleton and then released. Cell-to-cell transmission, e.g. in the skin and the lungs, is possible. The infected cell dies after a few days so that bleeding may result after endothelial cell infection. Whether the disease is overcome depends on rapid availability of cytotoxic CD8+ T lymphocytes from the host.

In addition to the skin and the vascular system, manifestation sites of a Rickettsia infection include interstitial pneumonia, interstitial myocarditis and perivascular haemorrhage in the brain, gastrointestinal duct and kidney.

The incubation period is $2-14$ days, on average 7 days. The body temperature rises above $39^{\circ} \mathrm{C}$.

In case of an $R$. conori infection, clinical outcome is usually mild. The course of the disease of this bacterium is similar to spotted fever. The bacterium occurs in South-East Europe, Africa, the Middle East up to Central Asia. The incubation period is 5-7 days. Clinical signs that stand out the most include swollen lymph nodes with a tendency to superficial haemorrhage at the inoculation site. In the body, the bacterium is usually spread via the blood pathways. The endothelial cells are massively infected. Deaths may occur.

The incubation period of $R$. akari is 10-17 days. The bacterium occurs in North America and Central Europe. In case of $R$. akari, one singular papule per inoculation is formed per bite 
from which a vesicle develops which droops centrally, bleeds inward and forms a scab. Regional lymph nodes are swollen. The disease is described as Rickettsia pox.

$R$. prowazekii is the pathogen of the endemic spotted fever (typhus), which has a world-wide distribution. Symptoms include spotted rash and fever which persists 8-10 days and can continue at a level of up to $40{ }^{\circ} \mathrm{C}$. The incubation period is 7-14 days. Initially severe headache and limb pain and the skin exanthema as from day 4-7 are typical symptoms. Depending on the nutritional situation of the infected individual, the death rate can be high (Napoleon army: more than 100,000 deaths). The patient often does not recover entirely. Relapses will then occur frequently, the so-called Brill-Zinsser disease (relapsing disease first described by Nathan Brill in New York in 1898 [67]). The epidemiological connection was established by Hans Zinsser in 1933 [68].

\subsubsection{Epidemiology}

$R$. akari and R. prowazekii occur world-wide. Transmission depends on the spreading of the vectors and the hygienic conditions. The concerned vector regions remain infectious for decades due to transovarial transmission since agricultural animals are also affected [69]. Wild-animal populations are only partly infected.

\subsubsection{Detection Methods}

\subsubsection{Culturing in Media}

If there is a history of the exposure and clinical symptoms, Rickettsia detection should be performed as early as possible during the infection phase by drawing heparin blood and transferring it onto culture cells. Approximately $0.5 \mathrm{ml}$ heparin blood or extracts of tissue samples are transferred to Vero, L929, HEL, or MRC5 cells before starting treatment of the patient with doxycycline. First growth of the bacteria can be seen after 2-3 days. Detection of Rickettsia is carried out by immunofluorescence or immune peroxidase staining. Culturing Rickettsia requires a biosafety level 3 laboratory.

\subsubsection{Antibodies}

Indirect immunofluorescence with commercially available Rickettsia-infected cells is still the standard. IgM and IgG detection are carried out separately. In addition, antibodies can be detected by latex agglutination ( $R$. rickettsii) and ELISA: ELISA assays for the various different Rickettsia types, including Orienta tsutsugamushi, are commercially available.

When evaluating the results, cross-reactions such as Weil-Felix reaction of Proteus vulgaris and Proteus mirabilis must also be taken into account. For the detection of an acute infection, it is the increase in titres that is of importance.

\subsubsection{NAT}

PCR is the most reliable method of Rickettsia detection. Reliable results are obtained if the gene of the $17 \mathrm{kDa}$ lipoprotein is amplified [70]. The results can be obtained in special laboratories within $6 \mathrm{~h} \mathrm{[71].}$

\subsection{Blood and Plasma Donors}

\subsubsection{Prevalence and Incidence in Donor Populations}

Routine testing of donors for antibodies or the bacterium is currently not indicated due to the current epidemiological situation. Antibodies against Rickettsia have been identified in blood donors in South France (prevalence 5-20\% [72]) and Malaysia (prevalence 15\% [73]). The Rickettsia antibody prevalence depends on the region. Thus, $8 \%$ was described for $R$. conorii and 2\% for $R$. typhi in North Greece [74], 7\% [75] for $R$. typhi in Central Spain and 74\% [76] for R. conorii in West Spain.

Since Rickettsia replicates in endothelial cells, it can be transmitted by blood transfusion in the acute, pre-clinical and relapsing phases. A case of $R$. rickettsiae transmission by blood transfusion was described in 1978, in which the recipient survived after treatment with antibiotics; the donor, however, did not [77].

\subsubsection{Definition of Exclusion Criteria}

History of tick bites, louse bites, louse infestation, and visits to endemic areas are valid exclusion criteria. The same applies to typical healing papules and scratch marks on the skin.

\subsubsection{Donor Testing and Significance}

In Germany, donors are not tested for Rickettsia antibodies or Rickettsia nucleic acid, and this is not required based on the current epidemiological situation.

\subsubsection{Donor Interviews}

In case of suspected infection, targeted questions on louse infestation and tick bite can contribute to the prevention of Rickettsia transmission by blood donation.

\subsubsection{Donor Information and Counselling}

Advice is indicated, if the donor's history requires this. This advice can also be given by physicians in an external centre with specialised knowledge.

\section{Yersinia pestis}

\subsection{Current Knowledge about the Pathogen}

Yersinia belongs to the family of Enterobacteriaceae. As psychrophilic bacterium, Yersinia is capable of replicating at $4{ }^{\circ} \mathrm{C}$. This ability plays an important part in transfusion medicine. Especially in the case of Yersinia enterocolitica, it can lead to a replication if stored in blood reserves [78]. Yersinia resides in the soil as well as in animals such as rodents, pigs and birds 
Fig. 4. Y. pestis. Photo taken using transmission electron microscopy. The length of the bacterium is approximately $1-2 \mu \mathrm{m}$.

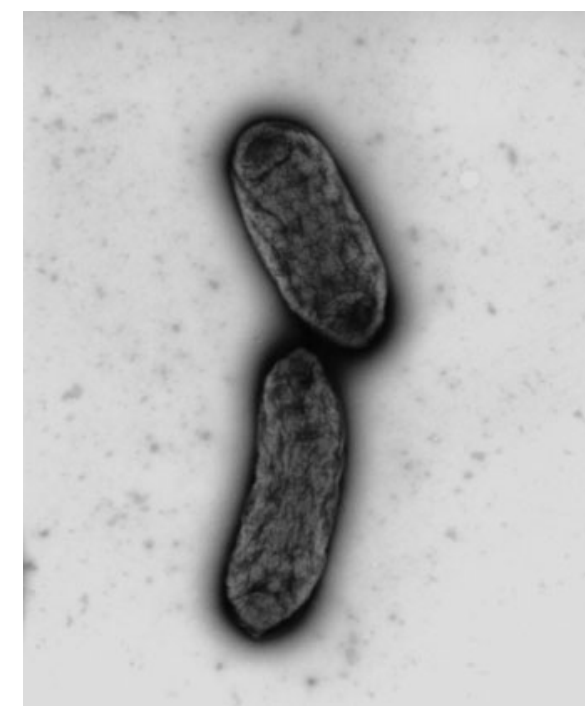

[79]. The plague, caused by $Y$. pestis, occurred in three major pandemics in history: Justinian Plague (531-580 AD), the plague of the 14th century, also known as 'The Black Death', and the Hong Kong Plague, which killed more than 100 million people [80].

\subsubsection{Characteristics of the Pathogen}

\subsubsection{Structure}

Y. pestis is a Gram-negative rod-shaped bacterium with a bipolar staining (giving it a safety-pin appearance, fig. 4). There are three distinct biovars of Yersinia: antiqua, mediaevalis, and orientalis. The virulence of $Y$. pestis depends on the presence of different plasmids. The $70 \mathrm{~kb}$ virulence plasmid encodes for the expression of the type-III secretion system, which lyses macrophages by contact-dependent injection of effector proteins into these macrophages, and for the $\mathrm{V}$ antigen. The 110 $\mathrm{kb}$ plasmid encodes for the factor of the anti-phagocytic fraction (Fra 1), and the $9.5 \mathrm{~kb}$ plasmid encodes for the temperature-dependent protease (plasminogen activator protein - Pla protease) $[80,81]$.

\subsubsection{Replication}

Y. pestis grows faster at $28^{\circ} \mathrm{C}$ and should be cultivated at $37^{\circ} \mathrm{C}$ for at least $48 \mathrm{~h}$. Virulent isolates grow at $37{ }^{\circ} \mathrm{C}$ as small colonies compared to avirulent ones. The expression of the genes is controlled on the plasmids depending on the growth temperature, thus influencing the virulence.

6.1.1.3 Extent to which the Bacterium Can Be Inactivated; Stability under Environmental Conditions

For general information, please refer to section 1.1.3. Similarly to other arbobacteria, e.g. C. burnetii and Francisella, Y. pestis is very resistant in the environment. The bacterium grows at temperatures as from $0{ }^{\circ} \mathrm{C}$, and also replicates in coagulated blood. However, the pathogen is sensitive to sun light and can easily be killed by high temperatures and disinfectant.

\subsubsection{Infection and Infectious Disease}

Pathogenicity is essentially influenced by the structure of the plasmid. This explains why $Y$. pestis strains with different degrees of pathogenicity occur in geographically restricted areas. The immune response in humans is based on antibodies and the rapid formation of cytotoxic $\mathrm{T}$ lymphocytes directed against virulence factors encoded by the $70 \mathrm{~kb}$ plasmid [82], and directed against Caf1 encoded by the $110 \mathrm{~kb}$ plasmid, a protein which acts as a chaperon [83].

\subsubsection{Rat Flea}

In the presence of the $9.5 \mathrm{~kb}$ plasmid, $Y$. pestis causes the sucked blood in the flea to coagulate, and Yersinia replicates in the coagulum. This leads to an inhibition of the intestinal motility so that the blood is regurgitated at the next sucking action, and thousands of Yersinia are injected into the skin of the rat or human.

\subsubsection{Human - Bubonic Plague}

This type of plague is the most common form of manifestation. Fever $\left(38.5-40^{\circ} \mathrm{C}\right)$ and chills suddenly occur within an incubation period of 2-7 days. Painfully swollen lymph nodes develop within few hours, which form part of the regional drainage area at the inoculation site of the rat flea. The size can be up to 10 $\mathrm{cm}$. Affected limbs - the bite usually occurs at the extremities are spared. Suppurating ulceration of the lymph node can occur. Papules and pustules can occur adjacent to the lymph nodes. There are signs of bacterial metastases. Bacteriaemia is detectable in $80 \%$ of the bubonic plague.

\subsubsection{Septic Plague}

If the bacteria cannot be retained in the lymph node, sepsis occurs. The patient rapidly becomes moribund. Primary sepsis without the lymph node swelling phase or without pneumonia might occur. If not treated, sepsis rapidly leads to death the preliminary phase of which is intravascular coagulation leading to peripheral suboptimal blood circulation making the skin appear deep purple, giving this disease its name 'Black Death'.

\subsubsection{Pneumonic Plague}

The lung is affected by inhalation of the pathogen or haematogenic dissemination of $Y$. pestis. Symptoms include tachypnoea, dyspnoea, cough and bloody sputum. The sputum is purulent. $Y$. pestis can be transmitted directly to individuals in the vicinity by its great number of bacteria in the secretion or sputum via smear infection or aerosol. Transmission from human to human, however, occurs very seldom. If left untreated, pneumonic plague leads to death.

\subsubsection{Treatment of Y.pestis}

Streptomycin or gentamycin is the treatment of choice. In addition, doxycycline and ciprofloxacine are also effective. Chloramphenicol is effective for the treatment of plague meningitis. Resistant $Y$. pestis strains are very rare in endemic regions. 


\subsubsection{Epidemiology}

Plague is a typical zoonosis, transmitted by vector bite. Its enzootic occurrence currently includes many natural endemic areas in many countries in Africa, the two Americas and Asia. Outbreaks occur annually with 100-1,000 affected individuals. Up to now, endemic areas for $Y$. pestis can be found in the south of Africa including Madagascar, Southern Russia to India, Mongolia, China, Indonesia, the west of North America, and the centre of South America.

Essentially, the hosts are rats (Rattus rattus, Rattus norwegicus), and the essential carrier is the rat flea (Xenopsylla cheopis). Other animal hosts include the gopher, the rabbit, the field mouse, and more seldom the dromedary. Other epidemiologically relevant vectors beside the flea are not known.

\subsubsection{Detection Methods}

In case of suspected $Y$. pestis infection, bacteriologic diagnostics must be performed in a biosafety level 3 laboratory.

\subsubsection{Antibodies}

Antibodies are detectable 1-2 weeks after occurrence of the symptoms. In approximately $5 \%$ of all infected individuals, no antibodies are detectable. ELISA assays have been developed for $\mathrm{IgM}$ and $\mathrm{IgG}$.

\subsubsection{Culturing in Media}

$Y$. pestis grows in most culture media, as mentioned above, better at $28{ }^{\circ} \mathrm{C}$ than at $37{ }^{\circ} \mathrm{C}$. Suitable culture media are McConkey blood and modified CIN (Cefsulodin Irgasan Novobiocin) agar in aerobic conditions. The small translucent colonies are detectable after $24-48 \mathrm{~h}$ depending on the temperature. Differentiation is carried out via biochemically detected enzyme performance and motility of $Y$. pestis, as well as via molecular biology and immunology methods.

\subsubsection{NAT}

Several methods have been published on the detection by means of PCR; above all, under the aspect that $Y$. pestis can be used as a biological weapon. An advantage of PCR compared with the tedious biochemical characterisation is that detection is possible directly from the colony material or even the sample, and that the presence of $Y$. pestis can be safely confirmed within approximately 2-3 h. Several real-time PCR assays have been described: Chase et al. [84] has used the chromosomal marker yp48 for the distinction of $Y$. pestis from other Yersinia types. Other tests are based on the detection of $Y$. pestis-specific plasmids [85, 86].

According to Section 6 of the German Infektionsschutzgesetz (Infection Protection Act), the detection of Y.pestis, clinically suspected $Y$. pestis infection, and the disease and death due to the pathogen are notifiable.

\subsection{Blood and Plasma Donors}

\subsubsection{Prevalence and Incidence in Donor Populations}

Since $Y$. pestis only occurs in endemic areas and outside Germany, no figures have been collected for Germany. Patients infected with $Y$. pestis show signs of acute inflammation and are therefore generally excluded from blood donation.

\subsubsection{Definition of Exclusion Criteria}

The general criteria for donors with signs of infection apply. Lymph node swelling and signs of fever are initial symptoms of the infection. The deferral for donors returning from tropical areas only applies to part of the individuals returning from endemic areas. Interviews on the donor history may help clarify an indication to an infection.

\subsubsection{Donor Testing and Significance}

Based on the epidemiologic situation, no infections due to blood donation have become known in the past few decades. Thus, testing for $Y$. pestis is currently not required.

\section{Facts about all Arbobacteria}

Arbobacteria can retain their ability to replicate in the soil or in water in fresh water amoebae for months, thus showing great resistance to the environment. Analogous with other non-spore formers, heating to $65-70{ }^{\circ} \mathrm{C}$ for $10 \mathrm{~min}$ and chemical treatment with $1 \%$ phenol, $5 \%$ hydrogen peroxide, $5 \%$ chloroform, $0.5 \%$ hypochlorite, and $5 \%$ formaldehyde for 10-30 min are considered as effective for inactivation. Disinfecting with $70 \%$ ethanol for $1 \mathrm{~min}$ also inactivates arbobacteria.

\subsection{Recipients}

\subsubsection{Prevalence and Incidence of Blood-Associated} Infections and Infectious Diseases in Recipient Populations Few data are available on the prevalence and incidence in recipients in Germany. Regionally different immunity, above all, exists for infections with Borrelia which depends on the tick occurrence, the infection of ticks with Borrelia, and the leisure time behaviour and profession of the recipient. For Anaplasma, Ehrlichia, Bartonella, Francisella and Rickettsia, antibody prevalences are in the low percentile. Exposure to $Y$. pestis is not assumed for persons living in Germany.

The following antibody prevalences are assumed according to a study by Raoult [1] in France:

- Bartonella: 0.1-0.001\%,

- Borrelia: 1-0.01\%,

- Francisella: 0.1-0.001\%,

- R. prowazekii: up to $35 \%$ infection rate in homeless individuals, 
- R. typhi: 0.001\%,

- Ehrlichia: 0.01\% in the USA [10].

\subsubsection{Immune Status (Resistance, Existing Immunity, Immune} Response, Age, Exogenous Factors)

The defence situation depends on the general state of the infected individual, his/her existing immunity, immunoreactivity, age and exogenous factors. The essential factor causing chronic outcome of the infection by arbobacteria results from the primarily intracellular growth of arbobacteria and continued change of the antigenic surface profile. Infectiousness of blood cannot be removed from blood entirely by leukocyte depletion since the bacteria are also present extracellularly.

Small amounts of free bacteria are removed by unspecific defence mechanisms, such as complement lysis, opsonisation and lipopolysaccharide-directed phagocytosis, as well as other mechanisms of the congenital immune defences. Since the defence mechanisms decrease with age, in over 60-year-olds chronic outcome and/or relapse of the infection must be expected after transmission of the infection (cf. Brill-Zinsser disease under $R$. prowazekii). Possible complications such as abscess formation, endocarditis, myocarditis, encephalitis and immunoreactive arthritis also occur more frequently in older individuals.

After transfusion of a bacterially contaminated blood reserve, first antibodies are detectable within 2-3 weeks as measurable immune response and the pathogen can be detected via NAT, at least in specialised laboratories, within 2-3 weeks at the earliest (cf. 6.1.4.3). Fulminant and rapidly deadly outcomes have been described for Bartonella, Francisella and Rickettsia infections in case of immune deficiency, especially caused by HIV [1]. For patients without immune deficiency diseases, primary major symptoms of arbobacteria transmission include high, partly relapsing fever, particularly induced by the released lipopolysaccharide (endotoxin). Fever does not necessarily occur in the case of an immune deficiency, nor does the typical lymph node swelling [87].

The further outcome for the infected receiver is basically determined by rapidly induced antibiotic treatment, as shown e.g. for $R$. rickettsii transmission by blood transfusion [77].

\subsubsection{Vaccination}

A vaccine has been developed only against $B$. burgdorferi, and has been used in approximately 450,000 individuals in the USA [88]. This vaccine has been withdrawn from the market because of the occurrence of unclarified arthritis which has been in questionable causal relationship with the vaccination. No vaccine has been available so far for humans against infection with the other arbobacteria. In animals, too, vaccine development is difficult. Thus, the vaccination has not been generally used against Afipia (Bartonella) felis in cats or against $C$. burnetii in sheep.

Vaccines against $R$. rickettsii were developed and also tested in Germany before and during World War II, above all for mili- tary interests, but could not reach pre-marketing stage due to inadequate protectiveness and considerable adverse effects [1] so that no vaccine is available today. Proteins influencing pathogenicity in $F$. tularensis infections have been successful in early vaccination attempts [89]. A live vaccine of $F$. tularensis with a deleted protein, which influences purin metabolism, creates immunity in mice protecting them from a deadly dose of the wild-type bacterium [90]. Partial immunity against $Y$. pestis with a vaccine consisting of Cafl protein can be created in mice [83].

\subsubsection{Severity and Course of the Disease}

About two thirds of the infections with arbobacteria have an asymptomatic and self-limiting outcome in immunocompetent individuals (see above). As the example of $R$. rickettsii shows, in case of clinical manifestation, a mild outcome and survival of the recipient is possible in case of early treatment (4th day), whereas the donor died without treatment [77]. Chronic arbobacteria infections manifest themselves with the usual signs of inflammation caused by bacterial toxins such as irregular febrile episodes, night sweat, exhaustion, fatigue, lymphatic adenopathy, arthritis of the small and large joints up to perivasculitis, endocarditis, myocarditis and encephalitis. Tick, louse and flea bites cannot always be identified from the patient's history. Since treatment is effective and without any major adverse effect, rapid antibiotic treatment should be started in case of suspected infection, even without specific pathogen identification; rapid treatment influences the survival rate, particularly in case of $Y$. pestis infection.

\subsubsection{Therapy and Prophylaxis}

\subsubsection{Therapy}

In case of unknown arbobacterium, doxycycline is the treatment of choice. Chloramphenicol, ampicilline, and cephalosporine are also very effective. As a rule, quinolone is effective in high dosages (750 mg twice daily for 5-7 days). Quinolone is only partly effective against Rickettsia. For Yersinia, a combination therapy with doxycycline and gentamicine should currently be the most effective one.

Since most pathogens, except for $Y$. pestis, grow intracellularly, treatment should continue for 2-3 weeks. Administration for a longer period is recommended if the nervous system is involved. Repeated infection, e.g. with Borrelia, will create partial immunity so that the Borrelia pathogens can be inactivated or eliminated via the immune system in case of re-infection without the occurrence of clinical symptoms.

\subsubsection{Prophylaxis}

In line with the main route of transmission, exposure to ticks and other vectors listed in Section 1.1 should be avoided in order to prevent infection. The pathogen can be transmitted by direct contact with Bartonella, Coxiella, Francisella and 
Yersinia. Contaminations with these bacteria have also occurred in the laboratory.

\subsubsection{Transmissibility}

In principle, arbobacteria can be transmitted by a vector (for an exception, see 7.1.4.2). All arbobacteria at least temporarily infect endothelial cells, macrophages and neutrophil granulocytes, and can cause temporary bacteriaemia. They are transmissible via blood and/or erythrocyte and thrombocyte concentrates, especially in the acute initial stage of the infection. However, infections by arbobacteria have so far not been reported in Germany.

\section{1.6 Frequency of Administration, Type and Amount of Blood Products}

Up to now, no transmission of arbobacteria via the blood which would be possible at the acute and the chronic stage of the infection has become known in Germany. Since the disease leads to signs of inflammation and to donor exclusion in compliance with the general guidelines, a large number of undiagnosed and unregistered transmissions should not be expected.

Transmission of arbobacteria via fresh frozen plasma is theoretically possible. Transmission by plasma derivatives can be excluded thanks to the manufacturing process since the bacteria are eliminated and inactivated entirely. Both heat inactivation and detergent treatment of plasma components will lead to loss of infectivity of the arbobacteria.

\subsection{Blood Products}

7.2.1 Infectious Load of the Starting Material and Test Methods Burden of blood or plasma with arbobacteria is unknown, but is to be considered as extremely low in Germany for reasons of infection epidemiology. For bacteria transmissible only by ticks, an accumulation of infections, if any, should only be seasonal; however, this has so far not been observed.

Since all arbobacteria also grow intracellularly and occur extracellulary, they cannot be removed from blood or cell-containing blood components.

\subsubsection{Methods for Removal and Inactivation of the Infectious Agent}

\subsubsection{Separation}

Arbobacteria cannot be removed from blood or cell-containing blood components. Leukocyte depletion can lead to pathogen reduction, e.g. for Ehrlichia, Francisella or Rickettsia, but cannot lead to complete removal.

In principle, bacteria can be removed from plasma by high revolution centrifugation or filtration over $0.22 \mu \mathrm{m}$ filters. Nei- ther method is feasible for fresh frozen plasma. Small bacteria such as Coxiella, Rickettsia and other arbobacteria types, but not Borrelia and Yersinia, can also penetrate filters of that pore size [2].

\subsubsection{Inactivation}

Arbobacteria can be inactivated by heat treatment $>65^{\circ} \mathrm{C}$ for $10 \mathrm{~h}$ or by pasteurising, e.g. at $60{ }^{\circ} \mathrm{C}$ for $10 \mathrm{~h}$. For Gram-negative bacteria, lipopolysaccharide is released from the cell wall by heat treatment. If administered i.v., lipopolysaccharide can lead to febrile reaction up to endotoxin shock.

In thrombocyte concentrates, arbobacteria can be inactivated by treatment with psoralen or similar substances.

\subsubsection{Feasibility and Validation of Procedures for Removal/ Inactivation of the Infectious Agent}

Arbobacteria can partly be replicated in cell culture to achieve quantities which allow spiking of blood or plasma. For $F$. tularensis ssp. tularensis, biosafety level 3 is required in compliance with the regulations for biological substances (BiostoffVerordnung), safety level 2 is required for Anaplasma, Bartonella, Borrellia and Ehrlichia.

Validation of the procedures for epidemiological reasons is currently not necessary, especially since no arbobacteria infection by blood transmission has become known.

\subsection{Assessment}

Arbobacteria are pathogens which grow intracellularly and can replicate also in endothelial cells and macrophages or granulocytes, and are transmissible by blood. If transmitted, the pathogens can cause severe and even deadly infections. If the course is chronic, the disease can be consuming with organ function impairment.

Prevalence of arbobacteria infections is very low in Germany, except for B. burgdorferi, $B$ afzelii and B. garinii infections, which can reach a prevalence of $10-30 \%$, particularly in endemic areas.

The generally low risk of transmission of arbobacteria can be further prevented if donors with reduced hygienic status are excluded from donation. Acutely and chronically infected blood donors are recorded by their clinical symptoms and by general donor exclusion criteria, and the exclusion criteria have proved to be effective.

The low significance of arbobacteria transmission is proved by the fact that no transfusion-related transmission has been reported in Germany in the past 30 years. Arbobacteria have currently no significance for the safety of blood products and plasma derivatives in Germany. 
This paper was completed on March 19, 2007 and approved by the German Advisory Committee Blood (Arbeitskreis Blut) on May 30, 2007. It was compiled by the members of the subgroup 'Assessment of Pathogens Transmissible by Blood' of the German Advisory Committee Blood (Arbeitskreis Blut):

\section{Prof. Dr. Lutz Gürtler}

Dr. Johannes Blümel

Prof. Dr. Reinhard Burger

Dr. Christian Drosten

Dr. Albrecht Gröner

Dr. Margarethe Heiden
Dr. Walter Hitzler

Prof. Dr. Dr. Bernd Jansen

Dr. Horst Klamm

Prof. Dr. Wolf-Dieter Ludwig

Dr. Thomas Montag-Lessing

Dr. Ruth Offergeld

Prof. Dr. Georg Pauli

Prof. Dr. Rainer Seitz

Dr. Uwe Schlenkrich

Dr. Volkmar Schottstedt

Dr. Hannelore Willkommen.

\section{References}

1 Raoult D: Introduction to rickettsiosis and ehrlichiosis; in Mandell GL, Bennett JE, Dolin R (eds) Principles and Practice of Infectious Diseases, 6th ed. Philadelphia, Elsevier, 2005, pp 2284-2287.

$\checkmark 2$ Arbeitskreis Blut, Untergruppe 'Bewertung Blutassoziierter Krankheitserreger': Coxiella burnetii Erreger des Q- (query) Fiebers. Bundesgesundheitsbl Gesundheitsforsch Gesundheitsschutz 2005; 48:814-821.

3 Houhamdi L, Lepidi H, Drancourt M, Raoult D: Experimental model to evaluate the human body louse as a vector of plague. J Infect Dis 2006;194: 1589-1596.

4 Maeda K, Markowitz N, Hawley RC, Ristic M, Cox D, McDade JE: Human infection with Ehrlichia canis, a leukocytic Rickettsia. N Engl J Med 1987; 316:853-856.

5 Walker DH, Dumler JS: Ehrlichia chaffeensis (human monocytotropic ehrlichiosis), Anaplasma phagocytophilum (human granulocytotropic anaplasmosis) and other Ehrlichiae; in Mandell GL, Bennett JE, Dolin R (eds): Principles and Practice of Infectious Diseases, 6th ed. Philadelphia, Elsevier, 2005, pp 2310-2318.

6 Hildebrandt A, Schmidt KH, Wilske B, Dorn W, Straube E, Fingerle V: Prevalence of four species of Borrelia burgdorferi sensu lato and coinfection with Anaplasma phagocytophila in Ixodes ricinus ticks in central Germany. Eur J Clin Microbiol Infect Dis 2003;22:364-367.

7 Wielinga PR, Gaasenbeek C, Fonville M, Boer AD, Vries AD, Dimmers W, Jagers GAO, Schouls LM, Borgsteede F, Giessen JWBVD: Longitudinal analysis of tick densities and Borrelia, Anaplasma and Ehrlichia infections of Ixodes ricinus ticks in different habitat areas in The Netherlands. Appl Envrion Microbiol 2006;72:7594-7601.

$>8$ Standaert SM, Yu T, Scott MA, Childs JE, Paddock $\mathrm{CD}$, Singleton NJ, Blaser MJ: Primary isolation of Ehrlichia chaffeensis from patients with febrile illness: clinical and molecular characteristics. J Infect Dis 2000;181:1082-1088.

$\checkmark 9$ Anderson BE, Sumner JW, Dawson JE, Tzianabos T, Greene CR, Olson JG, Fishbein DB, Olsen-Rasmussen M, Hollowau BP, George EH, Azad AF: Detection of the etiologic agent of human ehrlichiosis by polymerase chain reaction. J Clin Microbiol 1992;30:775-780.

10 Standaert SM, Dawson JE, Schaffner W, Childs JE, Biggie KL, Singleton J, Gerhardt RR, Knight ML, Hutcheson RH: Ehrlichiosis in a golf oriented retirement community. N Engl J Med 1995;333: $420-425$.
11 Brouqui P, Lecam C, Olson J, Raoult D: Serologicc diagnosis of human monocytic ehrlichiosis by immunoblot analysis. Clin Diag Lab Immunol 1994; 1:645-649.

12 Dreher UM, Fuente JDL, Hofmann-Lehmann R, Meli ML, Pusterla N, Kocan KM, Woldehiwet Z, Braun U, Regula G, Staerk KDC, Lutz H: Serologic cross-rectivity between Anaplasma marginale and Anaplasma phagocytophilum. Clin Diag Lab Immunol 2005;12:1177-1183.

13 Trofe J, Reddy KS, Stratta RJ, Flax SD, Somerville KT, Alloway RR, Egidi MF, Shokouh-Amiri MH, Gaber AO: Human granulocytic ehrlichiosis in pancreas transplant recipients. Transpl Infect Dis 2001; 3:34-39.

14 Leiby DA, Chung AP, Cable RG, Trouern-Trend J, McCullough J, Homer MJ, Reynolds LD, Houghton RL, Lodes MJ, Persing DH: () Relationship between tick bites and the seroprevalence of Babesia microti and Anaplasma phagocytophila (previously Ehrlichia sp) in blood donors. Transfusion 2002; 42:1585-1591.

15 Fingerle V, Goodman JL, Johnson RC, Kurtti TJ, Munderloh UG, Wilske B: Human granulocytic ehrlichiosis in Southern Germany; increased seroprevalence in high risk groups. J Clin Microbiol 1997;35:3244-3247.

16 Fingerle V, Munderloh UG, Liegl G, Wilske B: Coexsistence of Ehrlichia of the phagocytophila group with Borrelia burgdorferi in Ixodes ricinus from Southern Germany. Med Microbiol Immuno 1999; 188:145-149.

17 Del Prete R, Fumarola D, Fumarola L, Basile V, Mosca A, Miragliotta G: Prevalence of antibodies to Bartonella henselae in patients with suspected cat scratch disease (CSD) in Italy. Eur J Epidemiol 1999;15:583-587.

18 McGill S, Wesslen L, Hjelm E, Holmberg M, Rolf C, Friman G: Serological and epidemiological analysis of the prevalence of B spp antibodies in Swedish elite orienteers 1992-93. Scand J Infect Dis 2001;33:423-428.

19 Mallqui V, Speelmon EC, Verastegui M, MaguinaVargas C, Pinell-Salles P, Lavarello R, Delgado J, Kosek M, Romero S, Arana Y, Gilman RH: Sonicated diagnostic immunoblot for bartonellosis. Clin Diagn Lab Immunol 2000;7:1-5.

20 Handley SA, Regnery RL: Differentiation of pathogenic Bartonella species by infrequent restriction site PCR. J Clin Microbiol 2000;38:3010-3015.

21 Kordick DL, Breitschwerdt EB: Relapsing bacteriemia after blood transfusion of Bartonella henselae to cats. Am J Vet Res 1997;58:492-497.
22 Steere AC, Malawista SE, Snydman DR, Shope RE, Andiman WA, Ross MR, Steele FM: Lyme arthritis: An epidemic of oligoarticular arthritis in children and adults in three Connecticut communities. Arthritis Rheum 1977;20:7-17.

23 Bannwarth A: Chronische lymphozytäre Menigitis, entzündliche Polyneuritis und 'Rheumatismus'. Arch Psychiatr Nervenkrankh 1941;111:284-376.

24 Herxheimer K, Hartmann K: Über Acrodermatitis chronica atrophicans. Arch Dermatol Syph 1902;61: 57-76,255-300

25 Afzelius A: Bericht der Verhandlungen der Dermatologischen Gesellschaft zu Stockholm am 16 Dezember 1909. Arch Dermatol Syph 1910;101:405.

26 Fraser CM, Casjens S, Huang WM, Sutton GG, Clayton R, Lathigra R, White O, Ketchum KA, Dodson R, Hickey EK, Gwinn M, Dougherty B, Tomb JF, Fleischmann RD, Richardson D, Peterson J, Kerlavage AR, Quackenbush J, Salzberg S, Hanson $\mathrm{M}$, van Vugt R, Palmer N, Adams MD, Gocayne J, Weidman J, Utterback T, Watthey L, McDonald L, Artiach P, Bowman C, Garland S, Fuji C, Cotton MD, Horst K, Roberts K, Hatch B, Smith HO, Venter JC: Genomic sequence of a Lyme disease spirochete, Borrelia burgdorferi. Nature 1997; 390:580-586.

27 Schulte-Spechtel U, Lehnert G, Liegl G, Fingerle V, Heimerl C, Johnson BJB, Wilske B: Significant improvement of the recombinant Borrelia-specific immunoglobulin $\mathrm{G}$ immunoblot test by addition of VlsE and a DbpA homologue derived from Borrelia garinii for diagnosis of early neuroborreliosis. J Clin Microbiol 2003;41:1299-1303.

28 Ramamoorthi N, Narasimhan S, Pal U,Bao F, Yang XF, Fish D, Anguita J, Norgard MV, Kantor FS, Anderson JF, Koski RA, Fikrig E: The Lyme disease agent exploits a tick protein to infect the mammalian host. Nature 2005;436:573-577.

29 Wilske B, Schriefer ME: () Borrelia; in Murray PR, Baron EJ, Jorgensen JH, Pfaller MA, Yolken RH (eds): Manual of Clinical Micriobiology, 8th ed. Washington, DC, ASM Press, 2003, pp 937-954.

30 Steere AC: Lyme disease. N Engl J Med 1989; 321:586-596.

31 Wilske B, Münchhoff P, Schierz G, Preac-Mursic V, Roggendorf M, Zoulek G: Zur Epidemiologie der Borrelia burgdorferi-Infektion. Münch Med Wochenschr 1985;127:171-172.

32 Tomao P, Ciceroni L, Ovidio MCD, Rosa MD, Vonesch N, Iavicoli S, Signorini S, Ciarocchi S, Ciufolini MG, Fiorentini C, Papaleo B: Prevalence and incidence of antibodies to Borrelia burgdorferi and to tick-borne encephalitis virus in agricultural and forestry workers from Tuscany, Italy. Eur J Clin Microbiol Infect 2005;24:457-463. 
\$3 Lledo L, Gegundez MI, Saz JV, Beltran M: Screening of the prevalence of antibodies to Borrelia burgdorferi in Madrid province, Spain. Eur J Epidemiol 2004;19:471-472.

-34 Hauser U, Lehnert G, Lobentanzer R, Wilske B: Interpretation criteria for standardized western blots for three European species of Borrelia burgdorferi sensu lato. J Clin Microbiol 1997;35:1433-1444.

- 35 Nocton JJ, Dressler F, Rutledge BJ, Rys PN, Persing DH, Steere AC: Detection of Borrelia burgdorferi DNA by polymerase chain reaction in synovial fluid from patients with Lyme arthritis. N Engl J Med 1994;330:229-234

\36 Vasiliu V, Herzer D, Rössler D, Lehnert G, Wilske B: Heterogeneity of Borrelia burgdorferi sensu lato demonstrated by an OspA type specific PCR in synovial fluid from patients with Lyme arthritis. Med Microbiol Immunol 1998;187:97-102.

37 Nadal D, Wunderli W, Briner H, Hansen K: Prevalence of antibodies to Borrelia burgdorferi in forestry workers and blood donors from the same region in Switzerland. Eur J Clin Microbiol Infect Dis 1989;8:992-995.

\38 Bohme M, Schwenecke S,Fuchs E, Wiebecke D, Karch H: Screening of blood donors and recipients for Borrelia antibodies: no evidence of B. burgdorferi infection transmitted by transfusion. Infusionsther Transfusionsmed 1992;19:204-207.

\$39 Weiland T, Kühnl P, Laufs R, Heesemann J: Prevalence of Borrelia burgdorferi antibodies in Hamburg blood donors; in Kretschmer V, Stangel W, Wiebecke D (Hrsg): Transfusionsmedizin 1991/92. Beitr Infusionsther. Basel, Karger, 1992, vol 30, pp 92-95.

40 Johnson SE, Swaminathan B, Moore P, Broome CV, Parvin M: Borrelia burgdorferi: survival in experimentally infected human blood processed for transfusion. J Infect Dis 1990;162:557-559.

41 Nadelman RB, Sherer C, Mack L, Pavia CS, Wormser GP: Survival of Borrelia burgdorferi in human blood stored under blood banking conditions. Transfusion 1990;30:298-301.

42 Gerber MA, Shapiro ED, Krause PJ, Cable RG, Badon SJ, Ryan RW: The risk of acquiring Lyme disease or babesiosis from a blood transfusion. J Infect Dis 1994;170:231-234.

43 McCoy GM, Chapin CW: Bacterium tularense the cause of a plaque-like disease of rodents. US Public Health Hosp Bull 1912;53:17-23.

44 Francis E: The occurrence of tularemia in nature as a disease of man. US Public Health Rep 1921; 36:1731-1738.

45 Penn RL: Francisella tularensis (Tularemia); in Mandell GL, Bennett JE, Dolin R (eds): Principles and Practice of Infectious Diseases, 6th ed. Philadelphia, Elsevier, 2005, pp 2674-2685.

46 Ellis J, Oyston PC, Green M, Titball RW: Tularemia. Clin Microbiol Rev 2002;15:631-646.

47 Petersen JM, Schriefer ME: Tularemia: emergence/re-emergence. Vet Res 2005;36:455-467.

48 Barns SM, Grow CC, Okinaka RT, Keim P, Kuske CR: Detection of diverse new Francisella like bacteria in environmental samples. Appl Environ Micrbiol 2005;71:5494-5500.

49 Titball RW, Sjöstedt A: Francisella tularensis: an overview. ASM News 2003;11:558-563.

50 Berdal BP, Mehl R, Meidell NK, Lorentzen-Styr $\mathrm{AM}$, Scheel O: Field investigations of tularemia in Norway. FEMS Immunol Med Microbiol 1996; 13:191-195.

51 Brotcke A, Weiss DS, Kim CC, Chain P, Malfatti S, Garcia E, Monck DM: Identification of MglA-regulated genes reveals novel virulence factors in Francisella tularensis. Infect Immun 2006;74:6642-6655.
52 Staples JE, Kubota KA, Chalcraft LG, Mead PS, Petersen JM: Epidemiologic and molecular analysis of human tularemia, United States, 1964-2004. Emerg Infect Dis 2006;12:1113-1118.

53 Hall JD, Craven RR, Fuller JR, Pickless RJ, Kawula TH: Francisella tularensis replicates within alveolar type II epithelial cells in vitro and in vivo following inhalation. Infect Immun 2007;75:1034-1039.

54 Gurycova D, Kocianova E, Vyrostekova V, Rehacek J: Prevealence of ticks infected with Francisella tularensis in natural foci of tularemia in western Slovakia. Eur J Epidemiol 1995;11:469-474.

55 Hubalek Z, Sixl W, Halouzka J: Francisella tularensis in Dermatocenter reticularis ticks from the Czech Republic and Austria. Wien Klin Wochenschr 1998; 110:909-910.

56 Robert Koch-Institut: Tularämie: Ausbruch unter Teilnehmern einer Hasen-Treibjagd im Landkreis Darmstadt-Dieburg, 2005. Epidemiol Bull 2005;50: 465-466.

57 Tärnvik A: Nature of protective immunity to Francisella tularensis. Rev Infect Dis 1989;11:440-451.

58 Porsch-Ozcurumez M, Kischel N, Priebe H, Splettstosser W, Finke EJ, Grunow R: Comparison of enzyme-linked immunosorbent assay, Western blotting, microagglutination, indirect immunofluorescence assay, and flow cytometry for serological diagnosis of tularemia. Clin Diagn Lab Immunol 2004;11:1008-1015.

59 Bevanger L, Maeland JA, Naess AI: Competitive enzyme immunoassay for antibodies to a 43,000 molecular weight Francisella tularensis outer membrane protein for the diagnosis of tularemia. J Clin Microbiol 1989;27:922-926.

60 Fulop M, Leslie D, Titball R: A rapid, highly sensitive method for the detection of Francisella tularensis in clinical samples using the polymerase chain reaction. Am J Trop Med Hyg 1996;54:364-366.

61 Grunow RW, Spletstoesser W, McDonald S, Otterbein C, O'Brien T, Morgan C, Aldrich J, Hoffer E, Finke E, Meyer H: Detection of Francisella tularensis in biologiocal specimens using a capture enzyme-linked immunosorbent assay, an immunochromatochraphic handheld assay, and a PCR. Clin Diagn Lab Immunol 2000; 7:86-90.

62 Broekhuijsen M, Larsson P, Johansson A, Bystrom M, Eriksson U, Larsson E, Prior RG, Sjostedt A, Titball RW, Forsman M: Genome-wide DNA microarray analysis of Francisella tularensis strains demonstrates extensive genetic conservation within the species but identifies regions that are unique to the highly virulent $F$. tularensis subsp. tularensis. J Clin Microbiol 2003;41:2924-2931.

63 Higgins JA, Hubalek Z, Halouzka J, Elkins KL, Sjostedt A, Shipley M, Ibrahim MS: Detection of Francisella tularensis in infected mammals and vectors using a probe-based polymerase chain reation. Am J Trop Med Hyg 2000;62:310-318.

64 Khoury JA, Bohl DL, Hersh MJ, Argoudelis AC, Brennan DC: Tularemia in a kidney transplant recipient: an unsuspected case and literature review. Am J Kidney Dis 2005;45:926-929.

65 Vishwanath S: Antigenic relationships among the rickettsiae of the spotted fever and typhus group. FEMS Microbiol Lett 1991;81:341-344.

66 McDade JE, Shepard CC, Redus MA, Newhouse VF, Smith JD: Evidence of Rickettsia prowazekii infections in the United States. Am J Trop Med Hyg 1980;29:277-284.

67 Brill NE: An acute infectious disease of unknown origin. Am J Med Sci 1910;139:484-502.

68 Zinsser H: Varieties of typhus virus and the epidemiology of the American form of European typhus fever (Brill's disease). Am J Hyg 1934;20: 513-532.
69 Dupont HT, Brouqui P, Faugere B, Raoult D: Prevalence of antibodies to Coxiella burnetii, Rickettsia conorii, and Rickettsai typhi in seven African countries. Clin Infect Dis 1995;21:1126-1133.

70 Schriefer ME, Sacci JB, Dumler JS, Bullen MG, Azad AF: Identification of a novel rickettsial infection in a patient diagnosed with murine typhus. J Clin Microbiol 1994;32:949-954.

71 Tzianabos T, Anderson BE, McDade JE: Detection of Rickettsia rickettsii DNA in clinical specimens by using polymerase chain reaction technology. J Clin Microbiol 1989:27:2866-2868.

72 Raoult D, Toga B, Chaudet H, Chiche-Portiche C: Rickettsial antibody in southern France: antibodies to Rickettsia conorii and Coxiella burnetii among urban, suburban and semi-rural blood donors. Trans Roy Soc Trop Med Hyg 1987;81:80-81.

73 Tay ST, Kamalanathan M, Rohani MY: Antibody prevalence of Orienta tsutsugamushi, Rickettsia typhi and TT118 spotted fever group rickettsiae among Malaysian blood donors and febrile patients in the urban areas. Southeast Asian J Trop Med Public Health 2003;34:165-170.

74 Daniel SA, Manika K, Arvanmdou M, Antoniadis A: Prevalence of Rickettsia conorii and Rickettsia typhi infections in the population of Northern Greece. Am J Trop Med Hyg 2002;66:76-79.

75 Lledo L, Gegundez MI, Saz JV, Beltran M: Prevalence of antibodies to Rickettsia typhi in an area of the center of Spain. Eur J Epidemiol 2001;17: 927-928.

76 Ruiz-Beltran R, Herrero-Herrero JI, MartinSanchez AM, Martin-Gonzales JA: Prevalence of antibodies to Rickettsia conorii, Coxiella burnetii and Rickettsia typhi in Salamanca Province (Spain). Serosurvey in the human population. Eur J Epidemiol 1990;6:293-299.

77 Wells GM, Woodward TE, Fiset P, Hornick BB: Rocky mountain spotted fever caused by blood transfusion. J Am Med Ass 1978;239:2763-2765.

78 Arbeitskreis Blut, Untergruppe 'Bewertung Blutassoziierter Krankheitserreger': Yersinia enterocolitica. Bundesgesundheitsbl Gesundheitsforsch Gesundheitsschutz 1999;42:613-621.

79 Butler T, Dennis DT: Yersinia species, including plague; in Mandell GL, Bennett JE, Dolin R (eds): Principles and Practice of Infectious Diseases, 6th ed. Philadelphia, Elsevier, 2005, pp 2691-2708.

80 Prentice MB, Rahalison L: Plague. Lancet 2007;369: 1196-1207.

81 Perry RD, Fetherston JD: Yersinia pestis - etiologic agent of plaque. Clin Micrbiol Rev 1997;10:35-66.

82 Saikh KU, Kissner TL, Dyas B, Tropea JE, Waugh DS, Ulrich RG: Human cytolytic T cell recognition of Yersinia pestis virulence proteins that target innate immune response. J Infect Dis 2006;194: 1753-1760.

83 Chalton DA, Musson JA, Smith HF, Walker N, McGregor A, Lamb HK, Williamson ED, Miller J, Robinson JH, Lakey JH: Immunogenicity of a Yersinia pestis vaccine antigen monomerized by circular permutation. Infect Immun 2006;74: 6624-6631.

84 Chase CJ, Ulrich MP, Wasieloski LP, Kondig JP, Garrison J, Lindler LE, Kulesh DA: Real time PCR assays targeting a unique chromosomal sequence of Yersinia pestis. Clin Chem 2005:51:1778-1785.

85 Loiez C, Herwegh S, Wallet F, Armand S, Guinet F, Courcol RJ: Detection of Yersinia pestis in sputum by real-time PCR. J Clin Microbiol 2003;41: 4873-4875. 
86 Tomaso H, Reisinger EC, AlDahouk S, Frangoulidis D, Rakin A, Landt $\mathrm{O}$, Neubauer $\mathrm{H}$ : Rapid detection of Yersinia pestis with multiplex real-time PCR assays using fluorescent hybridisation probes. FEMS Immunol Med Microbiol 2003;38:117-126.

87 Hansmann Y, DeMartino S, Piémont Y, Meyer N Mariet P, Heller R, Christmann D, Jaulhac B: Diagnosis of cat scratch disease with detection of Bartonella henselae by PCR: a study of patients with lymph node enlargement. J Clin Microbiol 2005; 43:3800-3806
88 Simon MM, Birkner N, Lamers R, Wallich R: Outer surface lipoproteins of Borrelia burgdorferi: role in virulence, persistence of the pathogen and protection against Lyme disease; in Cabello FC, Hulinska D, Godfrey HP (eds): Molecular Biology of Spirochetes. Nato Science Series, I: Life and Behavioural Sciences. Fairfax, IOS Press, 2006, vol 373, pp 383-392.

89 Hepbrun MJ, Purcell BK, Lawler JV, Coyne SR, Petitt PL, Sellers KD, Norwood DA, Ulrich MP: Live vaccine strain Francisella tularensis is detectable at the inoculation site but not in blood after vaccination against tularaemia. Clin Infect Dis 2006;43: 711-716.
90 Pechous R, Celli J, Penoske R, Hayes SF, Frank DW, Zahrt TC: Construction and characterization of an attenuated prurine auxotroph in a Francisella tularensis live vaccine strain. Infect Immun 2006; 74:4452-4461.

91 Arbeitskreis Blut, Untergruppe 'Bewertung Blutassoziierter Krankheitserreger': Arboviruses Viruses transmissible by arthropods. Transfus Med Hemother 2005;32:24-32.

92 Paddock CD, Childs JE: Ehrlichia chaffeensis: a prototypical emerging pathogen. Clin Microbiol Rev. 2003;16:37-64. 